\title{
Anatomoclinical correlation and main radiological findings in a patient affected by
}

\section{Arnold Chiari's malformation: a review}

\author{
Correlação anatomoclínica e principais achados radiológicos em paciente acometidos pela \\ malformação de Arnold Chiari: uma revisão \\ Correlación anatomoclínica y principales hallazgos radiológicos en un paciente afectado por la \\ malformación de Arnold Chiari: una revisión
}

Received: 09/02/2020 | Reviewed: 09/12/2020 | Accept: 03/25/2021 | Published: 03/28/2021

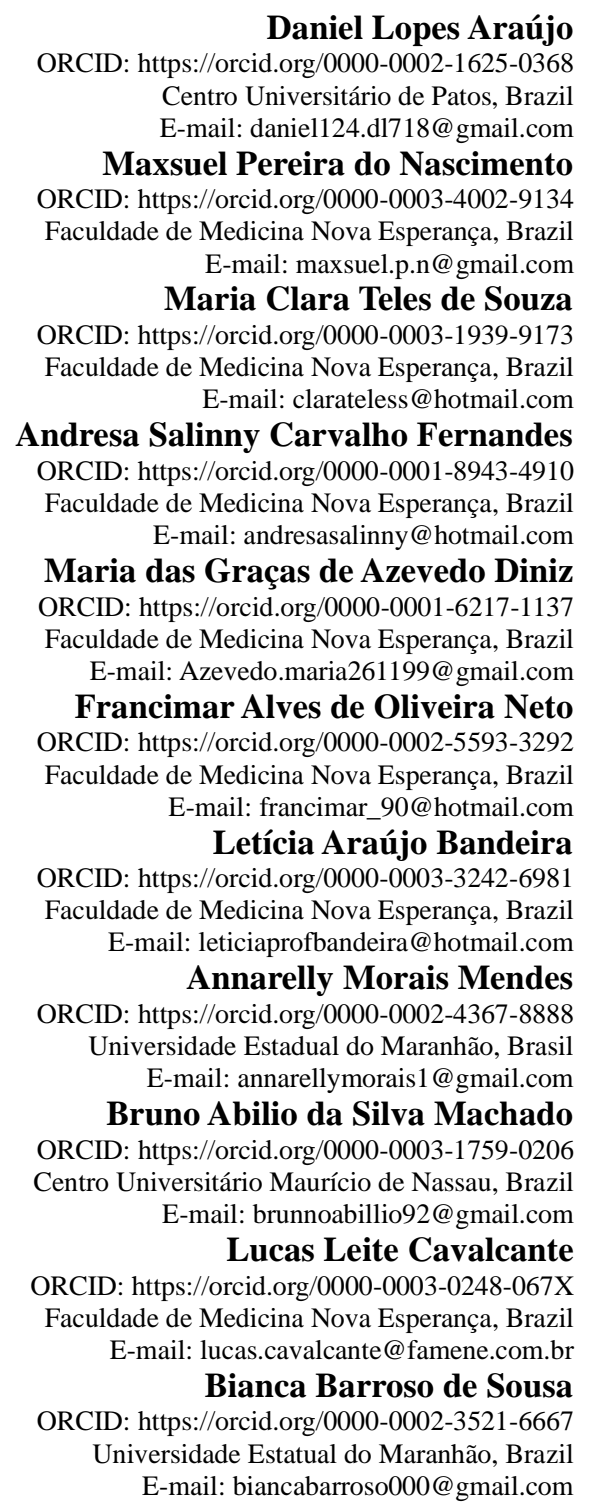

\begin{abstract}
Chiari's malformation is within the spectrum of congenital abnormalities of the central nervous system (CNS). It is characterized by a complex deformity of the posterior fossa associated almost always with a malformation of the spine. Chiari malformation is still a subject of little evidence in literature, where new studies on this parameter may trigger influences for researchers in the field. The objectives of this study were to describe the main alterations found in the nervous system in individuals with Chiari malformation. It is a literature review study. The following descriptors were used for the search: Chiari malformation, Posterior Pit and Craniovertebral Junction (together and
\end{abstract}


separately). In the selection criteria, full articles were chosen for the period: 2016 - 2019, in the languages: Portuguese and English. The searches were made in the databases: Scielo, Pubmed and Google academic. The articles were selected first by title, then by abstract, and finally by full reading. Based on the established criteria, 3 articles were selected that contemplate the theme. The literature shows that the most suggestive brain alterations of this pathology are cerebellar abnormalities such as caudal displacement of the bridge, IV ventricle and bulb; medullary torsion; IV ventricle in abnormal shape and hypoplasia of the cerebellum tent and mesencephalic ceiling. It is noticeable that Chiari's malformation can cause alterations that can vary from lighter to more severe. New studies are needed on this subject, as well as solutions to improve the quality of life of patients affected by this syndrome.

Keywords: Arnold Chiari malformation; Posterior pit; Cerebellar herniation.

\title{
Resumo
}

A malformação de Chiari encontra-se inserida no espectro de anormalidades congênitas do sistema nervoso central (SNC). É caracterizada por uma deformidade complexa da fossa posterior associada quase sempre a uma malformação da coluna vertebral. A malformação de Chiari ainda é uma temática de poucas evidências na literatura, onde novos estudos nesse parâmetro podem desencadear influências para pesquisadores da área. Os objetivos desse estudo foram descrever as principais alterações encontradas no sistema nervoso em indivíduos com malformação de Chiari. Trata-se de um estudo de revisão da literatura. Para tanto, foram utilizados para a busca os seguintes descritores: Malformação de Chiari, Fossa Posterior e Junção Craniovertebral (juntos e separados). No critério de seleção optou-se por artigos completos, no período de: 2016 - 2019, nos idiomas: português e inglês. As buscas foram realizadas nos bancos de dados: Scielo, Pubmed e Google acadêmico. Os artigos foram selecionados primeiramente por título, posteriormente por resumo, e por fim, por leitura completa. Diante dos critérios estabelecidos foram selecionados 3 artigos que contemplam o tema. A literatura mostra que as alterações encefálicas mais sugestivas dessa patologia são anormalidades cerebelares como deslocamento caudal da ponte, IV ventrículo e bulbo; torção medular; IV ventrículo em formato anormal e hipoplasia da tenda do cerebelo e do teto do mesencéfalo. É perceptível que a malformação de Chiari pode ocasionar em alterações que podem variar desde mais leve até a mais grave. Novos estudos são necessários acerca desta temática, bem como soluções para melhoria da qualidade de vida de pacientes acometidos por essa síndrome.

Palavras-chave: Malformação de Arnold Chiari; Fossa posterior; Herniação cerebelar.

\begin{abstract}
Resumen
La malformación de Chiari está dentro del espectro de anormalidades congénitas del sistema nervioso central (SNC). Se caracteriza por una compleja deformación de la fosa posterior asociada casi siempre a una malformación de la columna vertebral. La malformación de Chiari es todavía objeto de poca evidencia en la literatura, donde nuevos estudios sobre este parámetro pueden desencadenar influencias para los investigadores en el área. Los objetivos de este estudio fueron describir las principales alteraciones encontradas en el sistema nervioso de los individuos con malformación de Chiari. Este es un estudio de revisión de la literatura. Para la búsqueda se utilizaron los siguientes descriptores: malformación de Chiari, fosa posterior y unión craneovertebral (juntos y por separado). En los criterios de selección, optamos por artículos completos, en el período: 2016 - 2019, en los idiomas: portugués e inglés. Las búsquedas se hicieron en las bases de datos: Scielo, Pubmed y Google académico. Los artículos fueron seleccionados primero por el título, luego por el resumen y finalmente por la lectura completa. En base a los criterios establecidos, se seleccionaron 3 artículos que contemplan el tema. La literatura muestra que las alteraciones cerebrales más sugerentes de esta patología son las anormalidades del cerebelo como el desplazamiento caudal del puente, el ventrículo IV y el bulbo; la torsión medular; el ventrículo IV de forma anormal y la hipoplasia de la tienda del cerebelo y el techo mesencefálico. Es notable que la malformación de Chiari puede causar alteraciones que pueden variar desde las más leves hasta las más severas. Se necesitan nuevos estudios sobre este tema, así como soluciones para mejorar la calidad de vida de los pacientes afectados por este síndrome.
\end{abstract}

Palabras clave: Malformación de Arnold Chiari; Fosa posterior; Hernia Cerebelosa.

\section{Introduction}

Arnold Chiari syndrome (AC) is a congenital abnormality of the central nervous system (CNS). It is characterized by a deformity in the posterior fossa region (PF), and can be almost always associated with other types of pathologies and deformities at the base of the skull and craniovertebral junction, being these: basilar invagination (IB), platibasia, hydrocephaly, meningocele and cervical encephalocele, where if there is an association of two or more of these described pathologies the neuroanatonic and functional compromise can be even greater (de Magalhães et al., 2019; de Souza, 2019; Ribeiro, 2019).

This type of malformation can be divided into four other subtypes, which bring varied alterations, from the slightest to 
the most severe. Type I is characterized by the caudal displacement of the cerebellar tonsils by means of the foramen magnum; Type II is configured as the most common in the entire world population and happens when there is also herniation of the cerebellar tonsils, besides, there is herniation of the cerebellar worm and displacement of the ventricle IV; In type III, there is the herniation of the cerebellum or brainstem bringing in most of the times a high cervical meningocele; in type IV, there is little cerebellar development, being important to point out that there is no herniation in this case (Brock et al., 2017; Brito, 2019; Santos et al., 2020).

Nowadays, diagnostic confirmation can be made through analysis of more complex radiological imaging examinations, such as magnetic resonance imaging (MRI) and computed tomography (CT). MRI is considered by several authors to be the Radiodagnostic gold standard for evaluating these types of pathology, because it allows the measurement of the craniometric parameters of normality, which are: clivochannel angle (CCA), Welcker's basal angle basal angle of Welcker (ABW) and the distance from the odontoid to the Chamberlain line (DOLC), as well as a better visualization of structures that constitute the extension of the craniovertebral junction craniovertebral junction and posterior fossa (Vieira et al., 2018; Neto et al., 2018).

Starting for a clinical view, this type of anomaly can be asymptomatic and/or silent, mainly causing a deficit in the flow of cerebrospinal fluid and compression of the bulb. In addition, clinical symptoms found in patients with Chiari malformation can easily be confused with syndromes produced by FP tumors, multiple sclerosis or syringomyelia. The clinical picture may be occipital headache, posterior cervicalgia, vertigo, a feeling of faintness mainly when performing neck hyperextension, dyspnea, cranial nerve pairs with swallowing difficulties, speech articulation, paresis of upper and lower limbs (Rabelo et al., 2017; Biase et al., 2017; Gazzola, 2019).

The literature shows that magnetic resonance imaging (MRI) and computed tomography (CT) are the radiodiagnostic exams to help the clinical evaluation and subsequent diagnosis of this pathology. MRI is considered the gold standard exam for identification and analysis of CA (Araújo et al., 2020; Joaquim, 2020; Jesus, 2018).

In view of the above, the objective of this study was to demonstrate the anatomical and clinical aspects of Chiari's malformation, as well as its main radiological findings obtained from magnetic resonance imaging examinations.

\section{Methodology}

This work is a study of literature review of the integrative type. The methodological design used in the literature review work was made through the selection of scientific articles published in national and international journals ordered in the Scientific Electronic Library Online (SCIELO), LILACS, PubMed and Google Academic databases, being used the terminologies extracted from the Health Sciences Descriptors (DeCS): Arnold Chiari Malformation, Posterior Pit, Cerebellar Herniation.

The selection of the studies found was carried out in three stages: the first stage was made by reading the titles of the works found in the databases, in which all the articles describing the malformation were included. The second stage was carried out by reading the abstracts of the articles. Later, the last stage was through the reading of the complete works in their entirety.

The criteria for inclusion of the studies found in the search were: articles in the modality of literature reviews, case reports and case reports with free access to the database. We also selected articles with relevant theoretical basis on the theme, with a quantitative and qualitative approach. The languages chosen were Portuguese and English, the estimated time was between 2016 and 2020. The principles of exclusion of the articles found were: works that did not present a relevant approach on the subject, published before 2016 and duplicate studies in divergent databases. After filtering by inclusion and exclusion criteria, twenty articles were left, which were used in this work. 


\section{Results and Discussion}

Arnold Chiari Syndrome (MC) is one of the major malformations of the JCV in adults, and characterizes four rare anomalies that have a direct connection to the skull base. This pathology is configured by congenital or acquired herniation of the cerebellum through the foramen Magnum the foramen magnum, resulting in the compression of the brainstem. The CM can be type I, II, III and IV, where the involvement can cause severe alterations and cause severe problems. For some time now, the Arnold Chiari Malformation and its clinical implication, which is related to the reduction of the posterior fossa of the posterior fossa (PF), however, as the BI may be strongly associated with this malformation, the involvement of the PF may be even greater (Araújo et al., 2017).

In order to have a better understanding of what Arnold Chiari's malformation would be, it is necessary that first an anatomical description be arranged, so that in this way a better knowledge about this abnormality, as well as the main morphological points that this pathology can reach, can be unleashed. Table 1 exemplifies the subtypes of Chiari syndrome, showing the main radiological findings found on each of them.

Table 1. Chiari subtypes and main findings.

\begin{tabular}{ll}
\hline AC subtypes & Main findings \\
\hline Arnold Chiari I malformation & $\begin{array}{l}\text { Lower herniation of the cerebellar tonsils through the } \\
\text { foramen magnum. }\end{array}$ \\
Arnold Chiari II malformation & $\begin{array}{l}\text { Inferior herniation, through the foramen magnum, the } \\
\text { cerebellar worm, fourth ventricle and lower portion of } \\
\text { the brain stem. }\end{array}$ \\
Arnold Chiari III malformation & $\begin{array}{l}\text { There is occiput encephalocele with part of the } \\
\text { intracranial anomalies characteristic of Chiari type II } \\
\text { malformation. }\end{array}$ \\
Arnold Chiari IV malformation & $\begin{array}{l}\text { There is severe hypoplasia or cerebellum aplasia, } \\
\text { associated with the posterior fossa with small size } \\
\text { without herniation. }\end{array}$ \\
\hline
\end{tabular}

Source: Adapted from Araújo (2017).

Figure 1 shows an illustration of a sagittal cut magnetic resonance image showing an individual with Chiari type I malformation. This type is considered by specialists as the lightest degree of the disease and almost never brings symptoms, where the radiological findings and neuroanatomical alterations are minimal. 
Figure 1. MRI image, sagittal cut evidenced a patient with AC I. The hermiation of the cerebellar tonsils (blue arrow) is visible through the foramen magnum (green line).

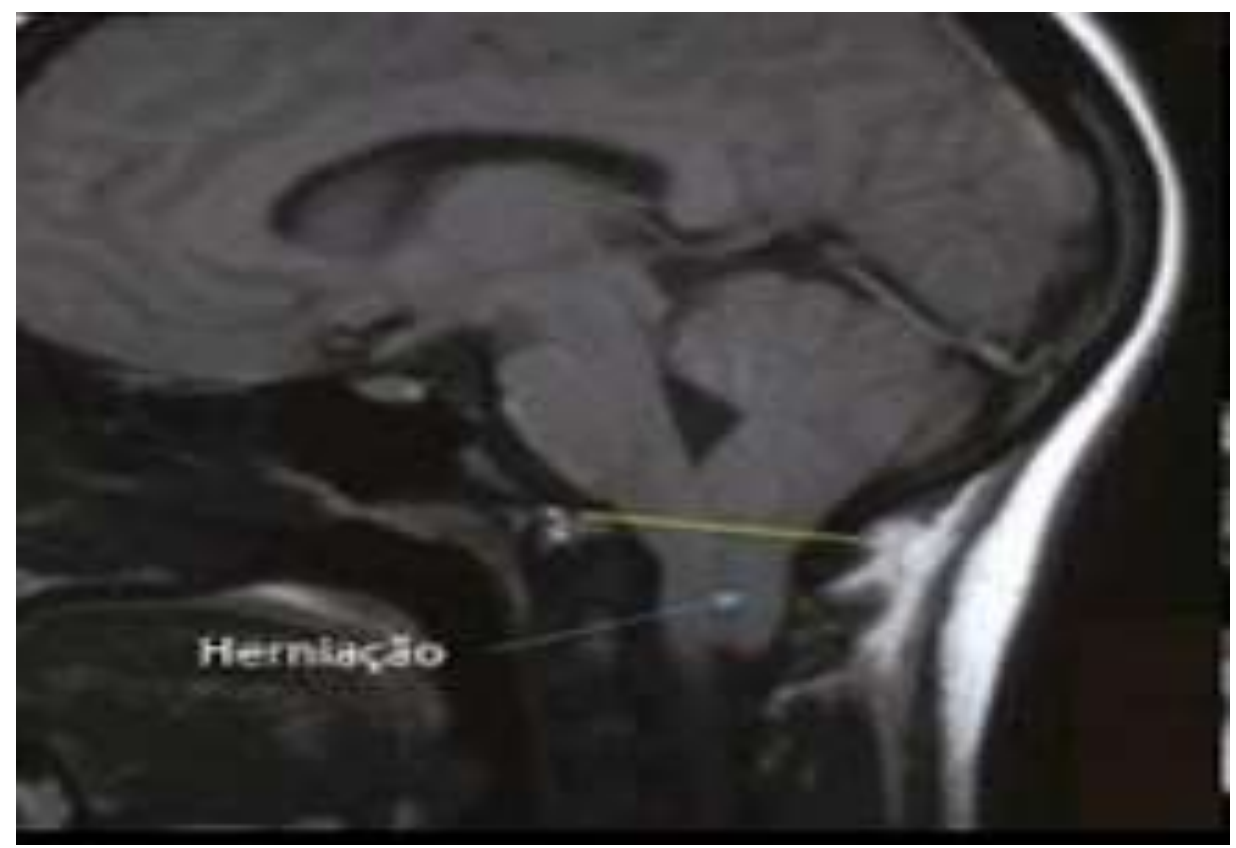

Source: Zorzi (2017).

In Figure 2 the illustration shows a patient with Chiari type II malformation. Epidemiological data prove that this is the most comenent type found in the world population. Chiari type II usually has associated hydrocephalus as the main complication. However, there may also be other symptoms such as headache, changes in vocal cords and respiratory system problems.

Figure 2. MRI image, sagittal cut, showing an AC II patient. Associated hydrocephalus, ventricular IV displacement (yellow arrow) and cerebellar hermiation (white arrow) are observed.

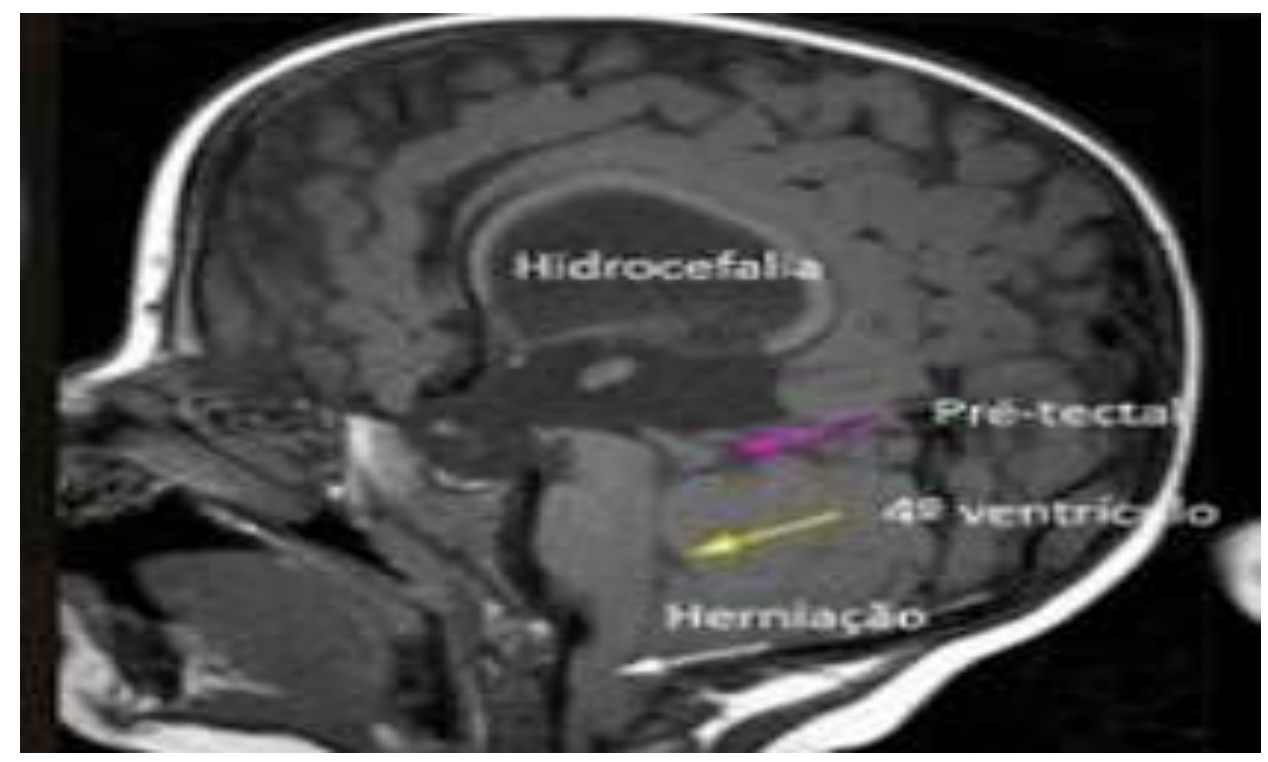

Source: Zorzi (2017).

In Chiari II, hard abnormalities are very common, such as the large, "open" heart-shaped temptress incisura and a thin, 
hypoplastic, fenestrated scythe, which allows spins to cross the middle line. Ventricular abnormalities are also frequently recognized in imaging examinations. They are present in more than 90\% of patients with MCII (Neto et al., 2018; Heringer et al., 2016).

Figure 3 shows Arnold Chiari's encephalocele malformation. Sagittal magnetic resonance imaging demonstrates a huge sac filled with CSF external to the skull later, with permeable communication with intracranial structures. There is herniation of both cerebellar hemispheres to the extruded CSF-filled sac. more consistent with an occiput encephalocele. The distortion of the brain stem and the absence of the corpus callosum are also evidente.

Figure 3. MRI image, sagittal section, individual with Arnold Chiari III malformation contained by an encephalocele.

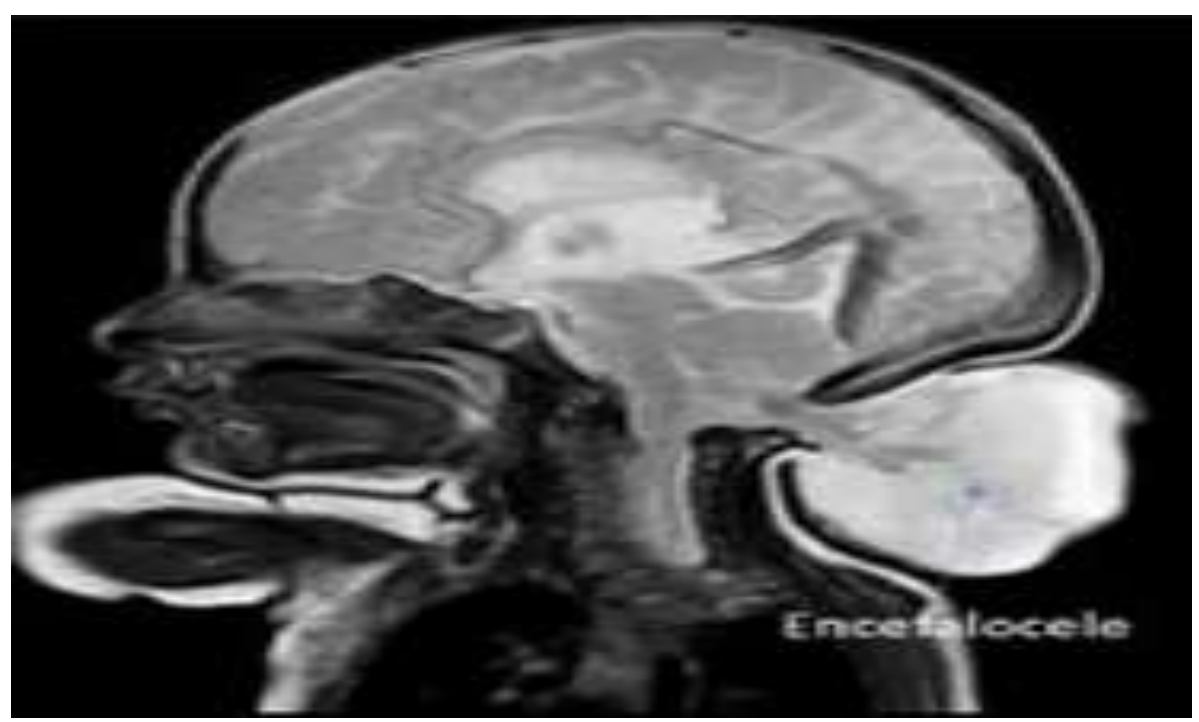

Source: Zorzi (2017).

Some factors such as the patient's age, the structure of the posterior skull fossa and the cervical medulla that has been compromised can lead to several prognoses, as well as neurological symptoms and the patient presents other pathologies. In view of this, it is of great relevance the previous clinical knowledge by the health professional in order to facilitate the diagnosis and a better treatment conduct for the patient (De Figuerêdo et al., Brock, 2017).

Among the different treatment modalities, the surgical procedures are the most recommended, one example is the peritoneal ventricle shunt (PVD), which is among the most used options for the correction of hydrocephalus, very often associated with this malformation and which has a relatively satisfactory level of acutracy. It is observed that there are divergent methods of derivation beyond the PVD. This surgery presents rates of considerable complications, such as infection, obstruction of the system and failures of the mechanical system of the device. Most of the time, due to neuroanatomic alterations of the PF, there is a need for surgical correction of this deformity through craniectomy of this part of the skull. This type of surgical treatment may or may not be correlated with laminectomy of the cervical spine. Currently, intrauterine treatment of this disease of myelomeningocele malformation has also been performed, bringing encouraging results when compared to other available treatment modalities. It is important to stress that this surgical treatment will depend on the type of Chiari and if it is associated with another type of malformation or skull base pathology (Sabba, 2017; Dahlem, 2016; Lobão et al., 2018).

\section{Conclusion}

The anatomical alterations in the face of this pathology are suggestive and may vary if there is an association with 
other deformities of the craniovertebral junction, leading to a greater impairment of where Chiari is inserted. The clinic and symptoms are specific and each type of Chiari presents particular signs and symptoms.

New studies are necessary in order to trigger the scientific basis for researchers and students in this area, as well as to find new solutions for improving the quality of life of patients affected by this abnormality.

\section{References}

Araújo, I. A., de Amorim, E. F., Santana, L. M. M., de Alencar, E. P., Araújo, M. I. A., \& Fernandes, P. E. Malformação de Arnold-Chiari: uma revisão bibliográfica

Araújo, D. L., Machado, B. A. da S., Falcão, C. P. M., Marques, L. L. B. L., Nascimento, M. P. do, Silva, M. D. S., Silva, A. C. F. da, Barbosa, M. G. A., Souza, M. C. T. de, Fernandes, A. S. C., Diniz, M. das G. de A., Silva, G. V. da, \& Souza, J. da S. (2020). Utilização da res sonância magnética para diagnóstico da esclerose múltipla. Research, Society and Development, 9(8), e546985936. https://doi.org/10.33448/rsd-v9i8.5936

Biasi, P. R., Roso, L. R. T., Manfroi, G., Espanhol, R. A., de Lacerda Almeida, T. A., Brunet, M. P., \& Crusius, M. U. (2016). Chiari IV Malformation, the Lückenschädel and Sagittal Craniosynostosis Association: Case Report and Literature Review. Arquivos Brasileiros de Neurocirurgia: Brazilian Neurosurgery, 35(01), 074-077.

Brito, J. N. P. D. O., Santos, B. A. D., Nascimento, I. F., Martins, L. A., \& Tavares, C. B. (2019). Basilar invagination associated with chiari malformation type I: A literature review. Clinics, 74

Brock, R. S., dos Santos, J. G. R. P., Taricco, M. A., de Oliveira, M. F., de Lima Oliveira, M., Teixeira, M. J., \& Bor-Seng-Shu, E. (2017). Dural Closure in Chiari I Malformation. Technique Description and Analysis of Results. JBNC-Jornal Brasileiro de Neurocirurgia, 28(2).

Brock, R. S. Ultrassonografia intraoperatória para avaliação da necessidade de duroplastia no tratamento cirúrgico de doentes com malformação de Chiari tipo I (Doctoral dissertation, Universidade de São Paulo).

Dahlem, C. S., Pereira, A. I., \& Gomes, T. V. (2016). Is spinal block safe for cesarean delivery?-a case report of a patient with uncorrected type 1 Chiari malformation. Revista da Sociedade Portuguesa de Anestesiologia, 25(4), 127-129.

de Figueirêdo Furtado, R. F., Carvalho, R. L., de Sousa, E. P., Coutinho, V. E. A., Moreira, J. A., \& Pinto, M. G. Malformações congênitas relacionadas ao sistema nervoso de récem-nascidos das macrorregiões do estado do Ceará.

de Magalhães, M. J. D. S., Pimenta, B. P. M., Gomes, H. O., Neto, J. V. F., de Oliveira, R. V., \& Novais, S. S. (2019). Alterações neuroanatômicas do encéfalo na malformação Arnold-Chiari II. Revista Eletrônica Acervo Saúde, (19), e710-e710.

de Souza, I. A., Gomes, M. B., Ramires, G. E., de Campos, F. F., \& Baracat, F. I. (2019). Malformação de Chiari i: relato de caso. Revista Uningá, 56(2), 4449 .

Gazzola, L. D. P. L. (2019). Malformações congênitas: reflexões médicas, jurídicas e bioéticas em busca da autonomia na gestação e na abordagem neonatal.

Heringer, L. C., de Oliveira, M. F., de Sousa, U. O., de Lima, W. C., \& Botelho, R. V. (2016). Improvement of Hydrocephalus in Patients with Chiari Malformation After Posterior Fossa Decompression. JBNC-Jornal Brasileiro de Neurocirurgia, 27(1), 71-73.

Jesus, N. O. D., Maruta, E. C. S., \& Azevedo, M. F. D. (2018). Hearing impairment in newborns and infants with myelomeningocele. AudiologyCommunication Research, 23.

Joaquim, A. F. (2020). Severe Cerebellar Degeneration and Chiari I Malformation-Speculative pathophysiology based on a systematic review. Revista da Associação Médica Brasileira, 66(3), 375-379.

Lobão, C. A. F., de Oliveira Sousa, U., Cabral, D. A. C., \& Campos, F. M. S. (2020). Hemifacial Spasm Associated with Chiari Type I Malformation: Surgical Considerations and Case Report. Arquivos Brasileiros de Neurocirurgia: Brazilian Neurosurgery, 39(02), $136-141$.

Neto, E. R., Brock, R., Paiva, W. S., Frigieri, G., Teixeira, M. J., \& Amorim, R. (2018). Monitoração não invasiva transoperatória da pressão intracraniana em paciente com malformação de Chiari tipo 1: relato de caso e prospecção do significado e aplicabilidade clínica do método. Arquivos Brasileiros de Neurocirurgia: Brazilian Neurosurgery, 37(S 01), A1494.

Rabelo, N. N., Pereira, V. H. H., Rocha, A. B., Guarnieri, I. C., Rabelo, N. N., Dias, L. A. A., \& Pereira, C. U. (2017). Brief historical note about Hans van Chiari (1851-1916). JBNC-Jornal Brasileiro de Neurocirurgia, 28(1), 13-15.

Ribeiro, E. C. D. O. (2019). Parâmetros do volume da fossa posterior na impressão basilar do tipo b na braquicefalia (Master's thesis, Brasil).

Sabba, M. F., Renor, B. S., Ghizoni, E., Tedeschi, H., \& Joaquim, A. F. (2017). Posterior fossa decompression with duraplasty in Chiari surgery: A technical note. Revista da Associação Médica Brasileira, 63(11), 946-949.

Santos, M. V., Furlanetti, L. L., Canheu, A. C., Bellas, A. R., da Silva, M. C., Cavalheiro, S., \& de Oliveira, R. S. (2020). Management of Chiari I deformity in Children and Adolescents: A report from the Consensus Taskforce of the Brazilian Society of Pediatric Neurosurgery. Arquivos Brasileiros de Neurocirurgia: Brazilian Neurosurgery, 39(02), 125-131. 